\title{
ELECTRICITY GENERATION FROM SWINE WASTEWATER USING MICROBIAL FUEL CELL
}

\author{
Chimezie Jason Ogugbue', Edegbai Egiolomhe Ebode', Solomon Leera²
}

1 Department of Microbiology, Faculty of Biological and Chemical Sciences, College of Natural and Applied Sciences, University of Port Harcourt, East-West Road, P.M.B. 5323 Choba, 500004 Port Harcourt, Nigeria, e-mail: ceejay55us@yahoo.com, jason.ogugbue@uniport.edu.ng

2 Department of Science Laboratory Technology, School of Science and Technology, Rivers State College of Arts and Science, P.M.B. 5936 Rumuola, Port Harcourt, Nigeria

Received: 2015.08 .24

Accepted: 2015.10 .06

Published: 2015.11.10

\begin{abstract}
Electricity generation from swine wastewater using microbial fuel cell (MFC) was investigated. Swine wastewater was collected into a dual-chambered (aerobic and anaerobic) fuel cell. The maximum power output using copper and carbon electrodes were 250.54 and $52.33 \mu \mathrm{W}$, respectively, while 10.0 and $5.0 \mathrm{~cm}$ salt bridge length between the cathode and anode gave maximum power outputs of 279.50 and $355.26 \mu \mathrm{W}$, respectively. Cathodic potassium permanganate and distilled water gave maximum power outputs of 1287.8 and $139.18 \mu \mathrm{W}$, respectively. MFCs utilized microbial communities to degrade organic materials found within wastewater and converted stored chemical energy to electrical energy in a single step. The initial bacterial and fungal counts were $7.4 \times 10^{6}$ and $1.1 \times 10^{3} \mathrm{CFU} \mathrm{ml}{ }^{-1}$. Bacterial counts steadily increased with time to $1.40 \times 10^{7} \mathrm{CFU}$ $\mathrm{ml}^{-1}$ while fungal count declined to $4.4 \times 10^{6} \mathrm{CFU} \mathrm{ml}^{-1}$ after day 60 . The decline in microbial counts may be attributed to the time necessary for acclimatization of microbes to the anode. The genera identified were Bacillus, Citrobacter, Pseudomonas, Lactobacillus, Escherichia coli, Aspergillus and Rhizopus. These microbes acted as primary and secondary utilizers, utilizing carbon and other organics of the wastewater. Chemical parameters indicated that the biochemical oxygen demand decreased from 91.4-23.2 $\mathrm{mg} / \mathrm{L}$, giving $75 \%$ while the chemical oxygen demand ranged from $243.1-235.2 \mathrm{mg} / \mathrm{L}$, representing $3.3 \%$ reduction. Although, the metabolic activities of microbes were responsible for the observed degradation, leading to electricity, the overall power output depended on the distance between the anode and cathode ompartments, types of electrode materials and mediators and oxygen reaction at the cathode.
\end{abstract}

Keywords: microbial fuel cell, electricity generation, swine wastewater, bacteria.

\section{INTRODUCTION}

The ever increasing demand for energy and its meagre supply in Nigeria and Africa in general have been a great challenge to economic development. This situation is becoming critical, with increasing population not balanced by an adequate energy development programme. The incessant power generation failure has grossly affected the economy, seriously slowing down the development in rural and sub-rural settlements, with present energy policy mainly benefiting urban dwellers [Lovley, 2006; Chris et al., 2008].
Energy projections stipulate that between 2002 and 2025, global energy needs may rise by over 34\%, with that of developing nations doubling this percentage [Larminie and Dick, 2000]. Hence, a robust solution must be found to ameliorate current energy crises. There is an emergent interest to use clean energy sources that are sustainable for wastewater treatment in order to effectively generate power using MFC other than fossil fuel.

Electricity generation using microbial fuel cell becomes a desired option. The microbial fuel cell (Figure 1) is a bio-electrochemical system 


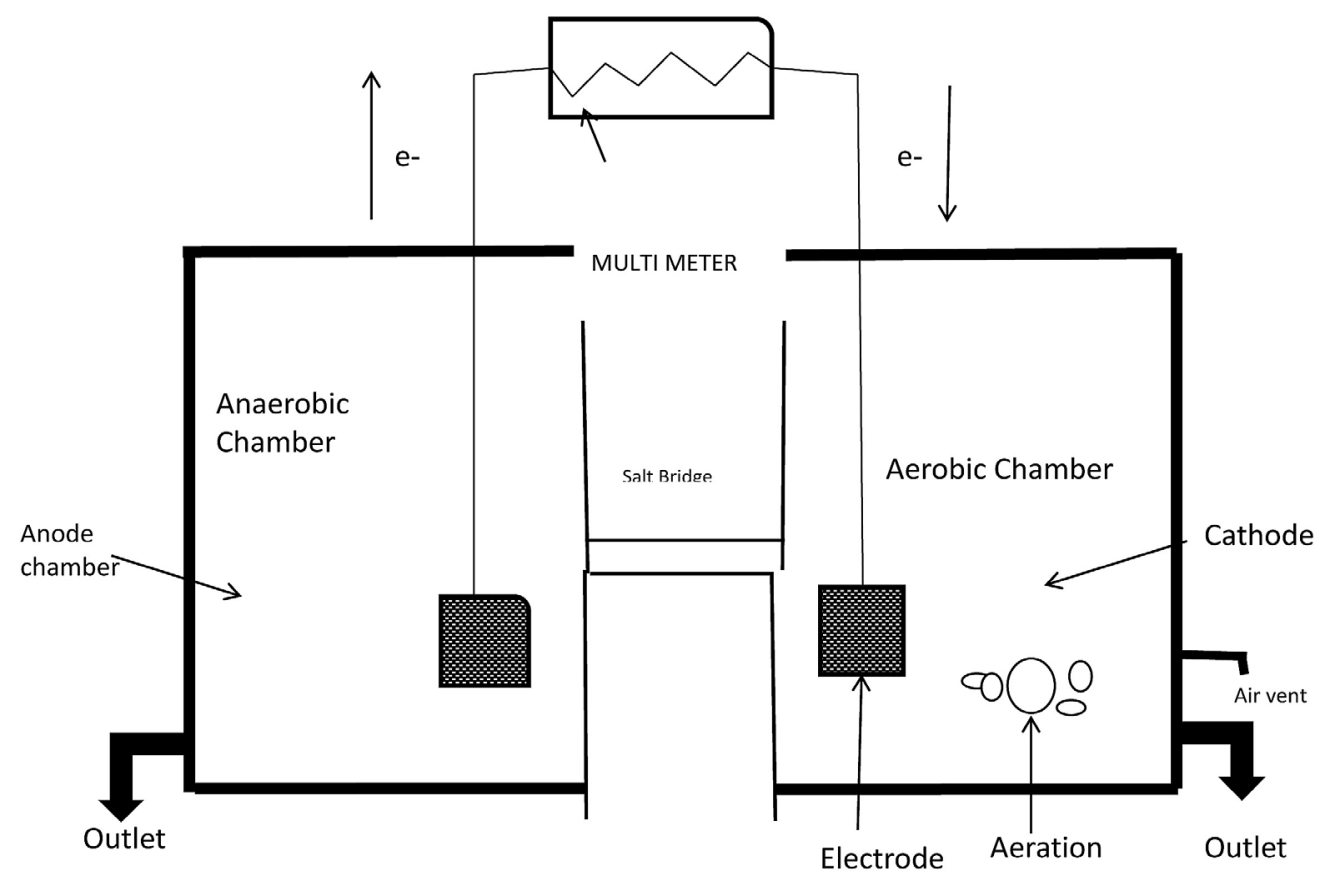

Figure 1. A schematic diagram of a dual chambered microbial fuel cell

in which microorganisms are used to catalyze the conversion of organic material into electricity [Barbir, 2005; Emily et al., 2012; Logan and Regan, 2006; Lovley, 2006; Nwachukwu, 2007; Surajit and Neelam, 2010 and Zhuwei et al., 2007; Feng et al., 2009; Pharm et al., 2006].

A microbial fuel cell (MFC) has a great potential to offer solution to this problem by generating direct electricity during oxidation of organic matter. MFCs have recently received increased attention as a means to produce 'green' energy from organic wastewater or synthetically prepared carbohydrate substrates [Ghangrekar and Shinde, 2008].

Bacteria can be used in MFCs to generate electricity while accomplishing the biodegradation of organic matters or wastes [Park and Zeikus, 2000; Oh and Logan, 2005]. The fuel cell is made of four parts: the anode, the cathode, the proton-exchange membrane (PEM) and the external circuit. The anode holds the bacteria and organic material in an anaerobic environment [Logan and Regan, 2006; Lovley, 2006]. The cathode holds a conductive saltwater solution. As part of the digestive process, the bacteria create protons $\left(\mathrm{H}^{+}\right)$and electrons $\left(\mathrm{H}^{-}\right)$.

The electrons are pulled out of the solution onto an electrode and are conducted through an external circuit [Ghangrekar and Shinde, 2008]. The electrons move through the circuit into the cathode (via cathode's electrode). The protons travel through the proton-exchange membrane or a salt bridge to meet with the electrons at the cathode [Rabaey and Verstraete, 2005; Surajit and Neelam, 2010].

The salt bridge is a mesh of proteins that separate the anode and cathode chambers, allows the protons to move from the anode to the cathode, but keeps the solutions in the anode and cathode separate. At the cathode, the protons and electrons combine with oxygen to create water [Ghangrekar and Shinde, 2008; Li et al., 2009]. MFCs can use a wide range of materials.

Organic materials can offer the intriguing capability of purifying waste and producing fresh water while also creating electricity [Venkata et al., 2007]. A MFC is considered ecologically friendly and can be used as a substitute to reduce greenhouse gases emission [Pham et al., 2006; Choi et al., 2000]. The advantages of using MFC in this situation as opposed to a normal battery is that it uses a renewable form of energy and need not to be recharged like a standard battery would.

In addition to this, they could operate well in mild conditions $\left(20-40{ }^{\circ} \mathrm{C}\right)$ and at $\mathrm{pH}$ of around 7.0 [Choi et al., 2000; Chris et al., 2008; Lovley, 2006; Pham et al., 2006]. The MFCs still need a significant breakthrough to become economically competitive. A previous study [Gil et al., 2003] has shown that the performance of MFC is determined by several factors which include microbial activities oxidizing fuels in the anode; electron transfer from microbial cells to the anode and proton transfer from the anode to cathode. In this 
study, swine wastewater was used as a substrate for electricity generation in a MFC. Furthermore, the effects of salt bridge length, comparative performance of carbon and copper electrode and the efficacy of using potassium permanganate $\left(\mathrm{KMnO}_{4}\right)$ as electron acceptor in cathode reaction were determined.

\section{MATERIALS AND METHODS}

\section{Sample collection}

Swine waste water samples were collected from Pig Farm Garden (PFG) in Aluu community, Rivers State, Nigeria. The samples were transported via a sterile jerry can to the environmental microbiology laboratory for analyses.

\section{Microbial fuel cell construction}

A dual-chambered MFC was constructed by connecting two plastic bottles (total volume of $1000 \mathrm{~mL}$ ) with a polyvinyl chloride (PVC) pipe of different lengths $(5.0 \mathrm{~cm}$ and $10.0 \mathrm{~cm})$. Each salt bridge had a diameter of $4 \mathrm{~cm}$ and contained a proton exchange membrane, clapped with two rubber loops. The salt bridge was made based on the method previously described [Logan, 2005; Venkata et al., 2007; Zhuwei et al., 2007].

The copper electrode was perforated at each edge through which copper wires were attached to the electrodes. The exposed areas were sealed with a non-conducting epoxy resin. The copper wires were then passed via the lid and connected to the external circuit and the graphite electrodes (length $=5.0 \mathrm{~cm}$, diameter $=0.6 \mathrm{~cm}$ ) passed through the $2.0 \mathrm{~mm}$ hole at the bottom side of the plastic material.

\section{Experimental setup}

The experiment was conducted for 60 days to study the effects of wastewater sample, electrode spacing, electrode materials and cathode solutions on MFC performance. In the first set of MFCs, the swine wastewater was sterilized in an autoclave and $800 \mathrm{ml}$ of the sterile sample fed into the anode chamber while the cathode chamber was injected with $800 \mathrm{ml}$ distilled water as an electron acceptor. For the remaining setups, unsterilized wastewater was used. To each of the MFCs, an unsterilized waste sample was added to the anode $(400 \mathrm{ml})$ and $\mathrm{KMnO}_{4}$ added to the cathode compartment $(400 \mathrm{ml})$ as mediator.
Again, the same procedure was repeated using water as the cathode mediator with a view to comparing the power output between water and $\mathrm{KMnO}_{4}$. In another set of tests, the effect of electrode distance $(5 \mathrm{~cm}$ and $10 \mathrm{~cm})$ was investigated. Two different types of electrodes (copper and graphite) were also used to evaluate their performance. The voltage and current were measured for the charged MFC daily using a digital multimeter (ALDA TD-830D) which was connected to the external circuit.

Daily readings were recorded and the conversion of data to power was done using the equation: $P=I \cdot V$. Where: $P$ - power (W), $I$ - current $(\mu \mathrm{A})$, and $V$-voltage (m Volt). The MFC was operated in a batch mode in which the swine wastewater was not replaced until MFC performance declined. Nitrogen gas was flushed into the anode to maintain anaerobic condition before closing the chamber.

\section{Microbiological analyses}

The total culturable heterotrophic bacterial counts (TCHBC) and total counts (TFC) of wastewater was determined in triplicate. A 10-fold serial dilution was done and $0.1 \mathrm{ml}$ spread-plated in triplicate as described by Pelczar et al. (1983). Nutrient agar plates were incubated for $24 \mathrm{~h}$ at $35 \pm$ $2{ }^{\circ} \mathrm{C}$ for bacterial enumeration and at $37{ }^{\circ} \mathrm{C}$ for $48 \mathrm{~h}$ using Sabauraud dextrose agar as the base medium for total fungi (TF) enumeration, respectively.

Discrete colonies that developed after incubation were transferred onto nutrient agar and potato dextrose agar slants for bacterial and fungal purification. Bacteria were identified based on cultural and biochemical characteristics [Holt et al., 1994] while fungal identification followed the most documented keys as described by Domsch et al. [1993].

\section{Determination of biochemical oxygen demand and chemical oxygen demand}

The method for biochemical oxygen demand (BOD) and chemical oxygen demand (COD) was adopted from APHA [1998]. The initial dissolved oxygen (DO) of the wastewater was diluted with oxygenated water and determined using Orion portable DO meter. The procedure was repeated after 5 days incubation period using Winkler method [Odiete, 1999; Singh et al., 1999].

The difference between DO at day zero and that at the fifth day multipled by the dilution fac- 
tor gives the $\mathrm{BOD}_{5}$. The amount of biodegradable organic matter present in the wastewater at a standard temperature of $20^{\circ} \mathrm{C}$ was then calculated by using the equation:

$\mathrm{BOD}$ or $\mathrm{BOD}_{5}=$ D.O. consumed in the test by the diluted sample $\mathrm{X}$ (Volume of the diluted sample divided by the Volume of the undiluted wastewater sample). The COD, a measure of total organic matter (biodegradable as well as non-biodegradable) was then determined [APHA, 1998; Carg and Garg, 2012]. The percentage degradation of BOD and COD was calculated using the expression:

$$
\% \text { degradation }=\frac{(I m g / L-F m g / L)}{I m g / L} \times 100
$$

Where $I$ is the initial value of the organics obtained and $F$ is the final value of the organics obtained. The data generated in the study was subjected to statistical analysis using the two way analysis of variance (ANOVA) to determine the levels of significance $(\mathrm{p} \leq 0.05)$.

\section{RESULTS AND DISCUSSION}

The batch system initially loaded with $400 \mathrm{~g}$ (anode chamber volume) of sterilized swine wastewater gave a potential difference of $0.044 \mathrm{~m}$ volts and $0.00 \mu \mathrm{A}$. The total culturable microbial counts of the waste water obtained show that there were changes in bacterial and fungal population with respect to time (Figure 2).

The initial total culturable heterotrophic bacterial counts (TCHBC) and total fungal (TF) counts were $7.4 \times 10^{6} \mathrm{CFU} \mathrm{ml}{ }^{-1}$ and $1.1 \times 10^{3} \mathrm{CFU} \mathrm{ml}^{-1}$, respectively. The THBC and TF counts steadily increased to a maximum count of $1.40 \times 10^{7} \mathrm{CFU}$ $\mathrm{ml}^{-1}$ and $4.4 \times 10^{6} \mathrm{CFU} \mathrm{ml}^{-1}$, respectively by day 60. The fungal genera isolated were identified based on their morphological characteristics with reference to Domsch et al. [1993].

\section{The effect of electrode type on the performance of microbial fuel cell}

Figure 3 shows the trend in power generation obtained in MFCs when different types of electrodes were used. Generally, higher power generation was obtained with copper electrodes than with carbon (graphite) electrodes.

When the MFC was operated with copper electrodes, the power generated increased from an initial output of $12.81 \mu \mathrm{W}$ to a peak of $251.54 \mu \mathrm{W}$ and subsequently decreased to a final value of $57.57 \mu \mathrm{W}$ during the eight (8) weeks of study.

Likewise, power output in the graphite electrode MFC followed a similar trend by increasing from $2.52 \mu \mathrm{W}$ to a peak of $52.26 \mu \mathrm{W}$ with a subsequent decrease to $8.448 \mu \mathrm{W}$ at the end of 8 weeks study period.

\section{The effect of salt bridge length on power generation in a microbial fuel cell}

The effect of electrode spacing on MFC performance was investigated by reducing the distance between the anode and cathode from $10 \mathrm{~cm}$ to $5 \mathrm{~cm}$. The maximum power output increased from $279.50 \mu \mathrm{W}$ to $355.26 \mu \mathrm{W}$ when the electrode distance was decreased to $5.0 \mathrm{~cm}$ (Figure 4) which also corresponded to a decrease of internal resistance. Higher power output was obtained in MFC with high positive oxidizing agent compared to salt water solution.

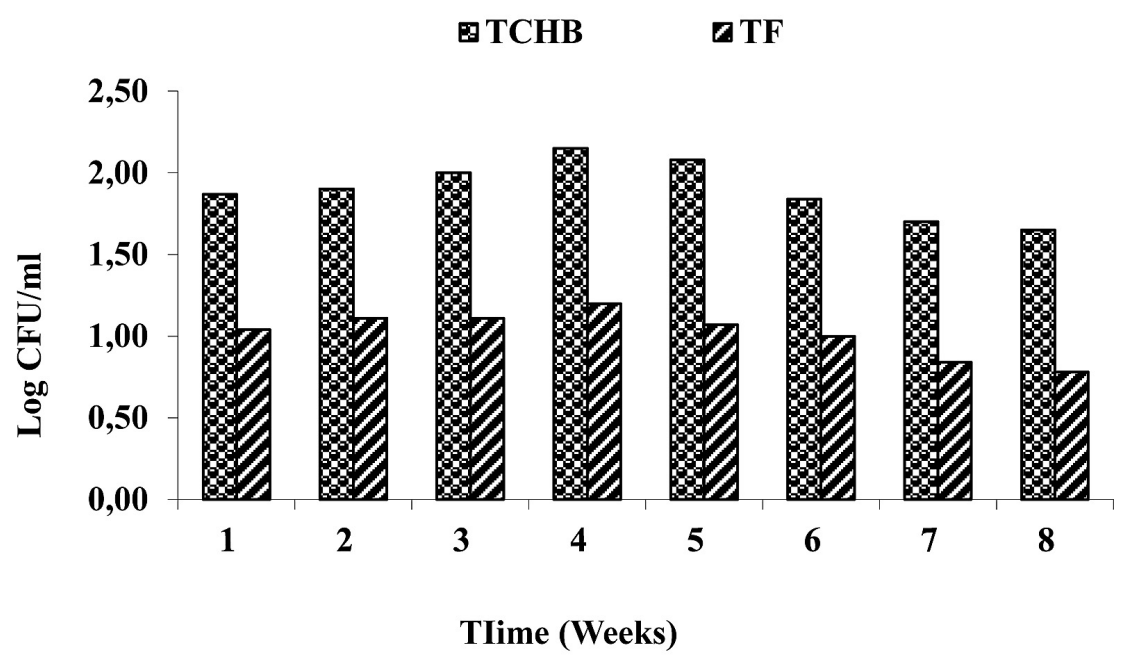

Figure 2. Microbial population changes in the anode with time during MFC operation 


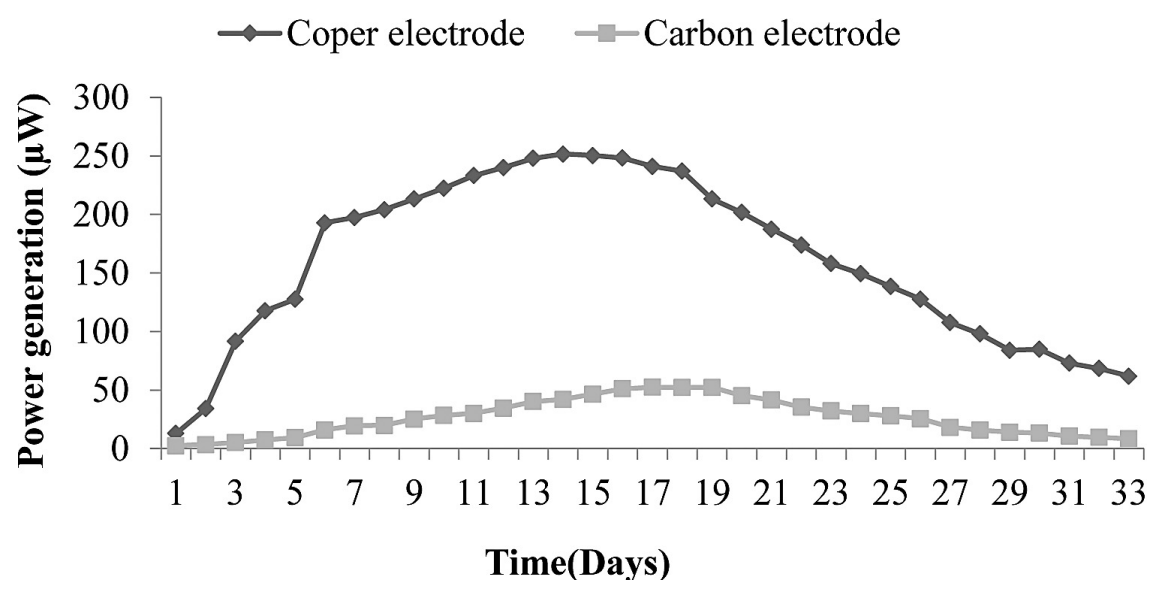

Figure 3. Influence of electrode type on power generation in a microbial fuel cell

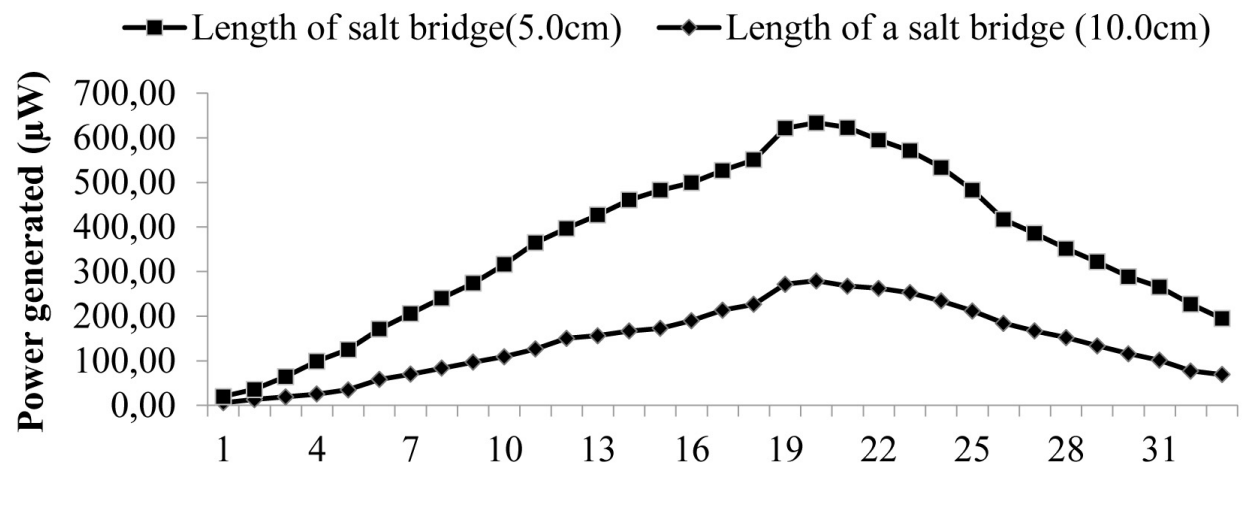

Time(Days)

Figure 4. Effect of salt bridge length on power generation in a microbial fuel cell

However, the power generated in the MFC with potassium permanganate $\left(\mathrm{KMnO}_{4}\right)$ solution in the cathode chamber was remarkably higher than that generated by distilled water solution as showed in the Figure 5. The potential difference of $0.044 \mathrm{~m}$ volts and $0.00 \mu \mathrm{A}$ obtained from the sterilized waste sample was as a result of the difference potential between the anode and cathode compartments.

While the $0.00 \mu \mathrm{A}$ obtained from the sterile waste sample shown that there were no microorganisms present in the waste to degrade it for the generation of protons and electrons.

\section{The effect of cathode reaction on power generation in the microbial fuel cell}

The major microbial genera isolated from the wastewater include Bacillus, Corynebacterium, Citrobacter, Staphylococcus, Micrococcus and Pseudomonas, Lactobacillus, Escherichia coli, Aspergillus, and Rhizopus. Some of these organisms acted as primary utilizers, utilizing the organic carbon of the wastewater while others acted as secondary utilizers, utilizing the breakdown products of other organics after initial attack by primary utilizers [APHA, 1998; Atlas, 1981].

This is an indication that oxidation and degradation was as a result of metabolic activities of the organisms and not due to abiotic factors. The low level of organic matter (BOD and COD) breakdown obtained initially from the wastewater may be attributed to the time necessary for the acclimatization of microbes to the anodic chamber.

The decline in circuit voltage and power output observed after the peak period may be linked to the depletion in nutrients and interaction between mixed cultures that produced some sort of toxins which may prevent the growth of microbes responsible for electron generation [Hadagali et al., 2012]. Figure 2 shows the effect of different electrode materials (copper and carbon) on circuit voltage (electron flow) of the MFC and power generation. Copper electrodes gave a higher circuit voltage and higher power output than carbon electrodes.

This may be attributed to high conductivity of copper when compared to carbon. Copper is a 
$\rightarrow \mathrm{KMnO} 4$ as cathode mediator $\rightarrow-$ Water as cathode mediator

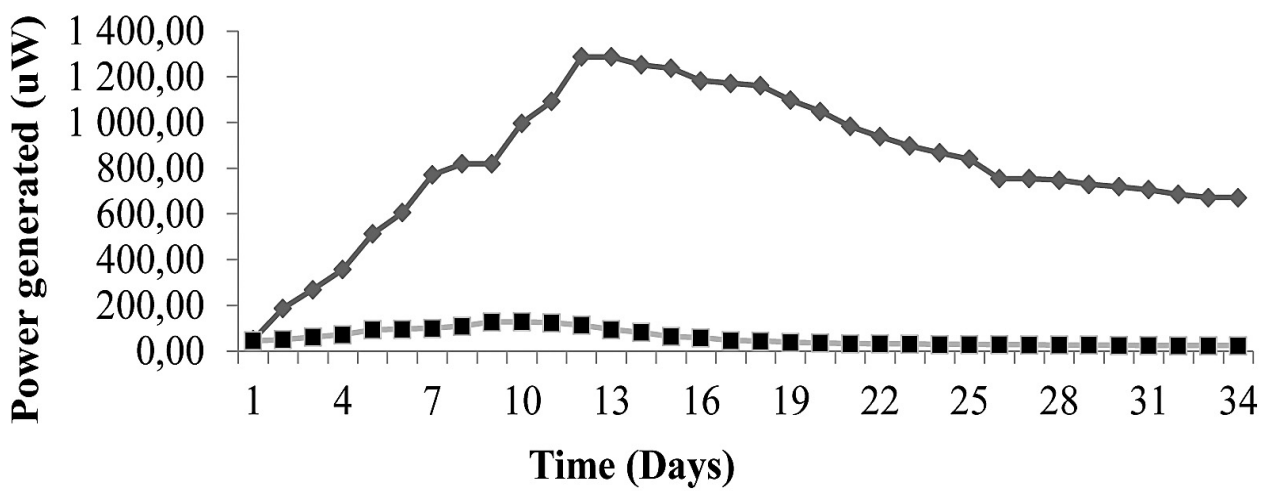

Figure 5. Effect of cathodic medium on power generation in a microbial fuel cell

good conductor and as such will allow electrons to pass easily to the external circuit. The higher the conductivity of the electrode material and the lower the contact losses and travel distance of the electrons within the electrode, the more efficient is the electron conduction and the lower the $\mathrm{Ohm}$ ic losses as well [Aelterman, 2009].

However, metal anodes consisting of noncorrosive stainless steel mesh may be preferable as copper cannot be used for a long time in a MFC due to its nature and the ease with which it corrodes. The result presented in Figure 5 showed that the distance between a cathode compartment and an anode compartment affected current generation. At $5 \mathrm{~cm}$ distance, a higher power output was obtained when compared to $10 \mathrm{~cm}$ distance which gave a lower output.

This indicates that, when the distance between two electrodes is reduced and the transfer distance of protons and the ohmic loses are reduced, the performance of a MFC is improved [Larminie and Dick, 2000; Ogugbue, 2015]. When the distance between an anode compartment and a cathode compartment is made as short as possible, the internal resistance is sufficiently reduced [Liu et al., 2005]. Hence, reducing the internal resistance is indeed a necessary means to enhance power generation in a MFC.

Potassium permanganate $\left(\mathrm{KMnO}_{4}\right)$ has been used as an eco-friendly oxidant in industries for many years [Oh et al., 2004]. Its high redox potential offers the possibility of its application in a fuel cell system to establish a high potential difference between the anode and the cathode [Shijie et al., 2006].

The power output obtained from the microbial fuel cell with permanganate was about ten times higher than that obtained from distilled water as shown in Figure 5. This is in agreement with the work of Shijie at al. [2006]. Such a volt increase is most likely due to the high redox potential of permanganate in acidic conditions. This shows that potassium permanganate solution is better for the cathode reaction in a MFC than distilled water [Shijie et al., 2006].

The biochemical oxygen demand (BOD) is that fraction of the total organic carbon in a system that is susceptible to microbial oxidation (biodegradation) [APHA, 1995]. The changes in chemical parameters revealed an initial BOD of $91.4 \mathrm{mg} / \mathrm{L}$. This was reduced by $75 \%$ to 23.2 $\mathrm{mg} / \mathrm{L}$ after day 60 . The initial high BOD value was probably due to the greater oxygen consumption in breaking down the organics in the wastewater resulting in higher BOD values which is in line with previous reports by Singh et al. (1999).

The chemical oxygen demand (COD) which is an indirect estimate of the total organic matter (biodegradable and non-biodegradable) of the system was decreased by $3.3 \%$ from $243.1-235.2$ $\mathrm{mg} / \mathrm{L}$ after day 60 . This represented the total organic content that was susceptible to the strong oxidizing agent $\left(\mathrm{KMnO}_{4}\right)$ used. Oxygen had been reported to be a necessary requirement in organic matter biodegradation [Atlas, 1981].

\section{CONCLUSIONS}

Swine wastewater is highly loaded with organic matter and other trace elements which are required for growth of mixed culture of organisms. MFCs utilize microbial communities to degrade organic materials found within wastewater and convert stored chemical energy to electrical energy in a single step. The study showed that 
power can be generated using swine wastewater and that the microorganisms needed for its operation were already present in the waste water.

The performance of the MFC with respect to power generation was found to be dependent on the electrode materials, distance between the anode, the cathode and the cathodic reaction. Oxygen is sometimes used as an electron acceptor for MFC due to its availability, sustainability and lack of chemical waste product, as the only end product is water. There was a lesser biocompatibility with carbon electrode than with copper electrode during the 60 days study period.

The results showed that for optimum operation of MFC, high oxygen consumption is required and the distance between the anode and cathode needs to be as close as possible. In deed, the real potential of MFCs in electricity generation has not been fully harnessed in developing countries; it is therefore, recommended that technological development in this area be enhanced to boost commercialization.

\section{Acknowledgements}

This research study was funded by the Nigerian Tertiary Education Trust Fund (Tetfund) Grant 2014.

\section{REFERENCES}

1. Aelterman P. 2009. Microbial fuel cells for the treatment of waste streams with energy recovery. PhD Thesis, Gent University, Belgium, 34-40.

2. APHA 1995. Standard methods for the examination of water and waste water. 19th ed. APHA-AWWA-WPCF. Washington D.C., 4, 85-137.

3. Allen R.M. and H.P. Bennetto 1993. Microbial fuel cells: electricity production from carbohydrates. Appl Biochem Biotechnol, 39-40, 27-40.

4. Atlas R.M. 1981. Microbial degradation of petroleum hydrocarbons: An environmental perspective. Microbiol. Rev. 45, 180-209.

5. Barbir F. 2005. PEM Fuel Cells: Theory and Practice. Burlington, MA, Elsevier, Inc. 567.

6. Bond D.R. and D.R. Lovley 2003. Electricity production by Geobacter sulfurreducens attached to electrodes. App. Environ. Microbiol. 69, 1548-1555.

7. Bullen R.A., T.C. Arnot, J.B. Lakeman, F.C. Walsh 2006. Biofuel cells and their development. Biosen. Bioelectron, 21, 20-45.

8. Choi Y., S. Jung, S. Kim 2000. Development of microbial fuel cells using proteus vulgaris. Bulletin of the Korean Chemical Society. 21 (1), 44-48.

9. Chris M., G. John, H. Ian, H. John, I. Ioannis 2008. Energy autonomy in robots through microbial fuel cells. IAS Lab, CEMS Faculty, Applied Sciences Faculty, University of the West of England, 432-234.

10. Domsch K.H., W. Gams, T.H. Anderson 1993. Compendium of soil fungi. Academic Press., London, 860.

11. Emily J., G.E. Mark, N.P.T. Grisdela Jr., P.R. Girguis 2012. Duty cycling influences current generation in multi-anode environmental microbial fuel cells. Environ. Sci. Technol. 46, 5222-5229.

12. Feng Z., C.T. Robert, S.J.R. Varcoe 2009. Techniques for the study and development of microbial fuel cells: an electrochemical perspective. Afr. J. 234-453.

13. Ghangrekar M.M., and V.B. Shinde 2008. Simultaneous sewage treatment and electricity generation in membrane-less microbial fuel cell, IWA Publishing Water. Sci. \& Technol. WST. 58.1.

14. Gil G.C., I.S. Chang, B.H. Kim, M. Kim, J.K. Jang, H.S. Park and H.J. Kim 2003. Operational parameters affecting the performance of a mediator-less microbial fuel cell. Biosens. Bioelectron. 18, 327-334.

15. Garg S.K. and R. Garg 2012. Environmental studies and green technologies. Khanna Publishers, Nai Sarak Delhi, 254-255.

16. Hadagali A., R. Shalini and P. Bhat 2012. Comparative Studies On Electrodes for the Construction of Microbial Fuel Cell. Intl. J. Adv. Biotechnol. Res. 3(4), 785-789.

17. Holt J.G., N.R. Krieg, P.H.A. Sneath, J.F. Stanley and S.T. Williams 1994. Bergey's Manual of Determinative 19th edition. Williams and Wilkins's, Baltimore, Maryland, USA.

18. Larminie J., A. and A. Dick 2000. Fuel Cell Systems Explained, the application of Microbial fuel cell. Appl. Biochem. Biotech., 61-107.

19. Li Z., X. Zhang, Y. Zeng and L. Lei 2009. Electricity production by an overflow-type wetted microbial fuel cell. Bior. Technol. 100, 2551-2555.

20. Liu H., S. Grot and B. Logan 2005. Electrochemically assisted microbial production of hydrogen from acetate, Environ. Sci. \& Technol. 39(11), 4317-4320.

21. Logan B.E. 2005. Building a two-chamber microbial fuel cell after a tutorial presented by the Logan Group. 554

22. Logan, B.E and J.M. Regan 2006. Microbial fuel cells - challenges and applications. Environ Sci. Technol., 40, 5172-5180.

23. Lovley D.R. 2006. Bug juice: harvesting electricity with microorganisms. Nat. Rev. Microbiol. 4, 497-508. 
24. Nwachukwu G.N. 2007. Microbial fuel cells and parameters affecting performance when generating electricity MMG 445. Basic Biotechnol. J. 3, 73-79.

25. Pelczar, M.J.Jr. R.D. Reid and E.C.S. Chan 1983. Microbiology. Tata McGraw Hill Publishing Company Ltd. New Dehli pp. 845.

26. Park, D.H. and Zeikus JG. 2000. Electricity generation in microbial fuel cells using neutral red as an electronophore. Appl. Environ. Microbiol. 66, 1292-1297.

27. Pham, T.H., K. Rabaey, P. Aelterman, P. Clauwaert, L. De Schamphelaire, N. Boon and W. Verstraete 2006. Microbial fuel cells in relation to conventional anaerobic digestion technol. Eng. Life Sci. 6, 285-292.

28. Odiete W.O. 1999. Hydrocarbons pollution. In: Environmental Physiology of Animals and Pollution. Diversified Resources Ltd. Lagos, Nigeria, 1, 180-192.

29. Oh S.E. and B.E. Logan 2005. Hydrogen and electricity production from a food processing wastewater using fermentation and microbial fuel cell technologies. Water Res. 39, 4673-4682.

30. Oh, S.E, Min B, Logan BE. 2004. Cathode performance as a factor in electricity generation in microbial fuel cells. Environ. Sci. Technol. 38, 4900-4944.

31. Ogugbue C.J. 2015. Detoxifying and making the environment safe for human habitation. In: Unique Uniport Publication (Special Convocation Edition, June-Sept.), 51-52.
32. Rabaey K. and W. Verstraete 2005. Microbial fuel cells: novel biotechnology for energy generation. Trends. Biotechnol. 23, 291-298.

33. Singh H.P., J.P. Mishra and L.P. Mahaver 1999. Observation on biochemical and chemical oxygen demands of certain polluted stretch of river Ganga. J. Environ. Biol. 20(2), 111-114.

34. Shijie Y.A., Z. Qingliang, Z. Jinna, J. Junqiu and J.Z. Shiqi 2006. A microbial fuel cell using permanganate as the cathodic electron acceptor. J. of Pow. Sour. 162, 1409-1415.

35. Sourish K.1., K. Kundu and S.I. Kundu 2010.Design and Development of Microbial Fuel cells. 445-463.

36. Surajit, D. and M. Neelam (2010). Recent developments in microbial fuel cells: a review. J. Sci. and Ind. Res. 69, 727-731.

37. Venkata M.S., G. Mohanakrishna, S. Srikanth and P.N. Sarma 2008. Harnessing of bioelectricity in microbial fuel cell (MFC) employing aerated cathode through anaerobic treatment of chemical wastewater using selectively enriched hydrogen producing mixed consortia. Fuel. 87, 2667-2676.

38. Venkata M.S., R.S. Veer, S. Srikanth and P.N. Sarma 2007. Bioelectricity production by meditor-less microbial fuel cell (MFC) under acidophilic condition using wastewater as substrate: influence of substrate loading rate. Curr. Sci. 92(12), 1720-1726.

39. Zhuwei, Du A., H.A. Li, and Gu B. Tingyue 2007. A state of the art review on microbial fuel cells: A promising technology for wastewater treatment and bioenergy. Biotechnol. Advan. 25, 464-468. 